\title{
Implementation of the loT Concept in Air Conditioning Control System Base on Android
}

\author{
Ali A.S. Ramschie \\ Department of Computer \\ Engineering \\ Manado State Polytechnic
}

\author{
Johan F. Makal \\ Department of Electrical \\ Engineering \\ Manado State Polytechnic
}

\author{
Veny V. Ponggawa \\ Department of Computer \\ Engineering \\ Manado State Polytechnic
}

\begin{abstract}
One of the things that can cause a waste of electricity from operating air conditioning equipment, is the operation of the equipment continuously, even though no one is in the room, or the home owner forgets to turn off the air conditioning equipment when leaving the house. For this reason, it is necessary to create a system that can control the work of AC equipment remotely, by applying the concept of the Internet of Things (IoT), where control is carried out via an android smart phone device. These controls include on / off process, operating modes and temperature settings, so that equipment operation is more effective and can avoid wasting electrical energy. The method used in this research is the prototyping method, which includes the stages of literature studies, field studies and data collection, the design stages of both software and hardware design for system requirements, the manufacturing stages of both hardware and software, and the system work testing stage. The results show that the system created can carry out the process of controlling the work of air conditioning equipment remotely via an Android Smartphone device, for the on / off process, setting the operating mode and setting the temperature of the air conditioning equipment.
\end{abstract}

\section{Keywords}

Android, IoT, Control, Air Conditioning.

\section{INTRODUCTION}

Things that can be done to minimize the waste of electrical energy from operating air conditioning equipment, is in terms of controlling the work of the air conditioning equipment. Control can be done by adjusting the work of the air conditioning equipment for the air conditioning process, based on the number of people in the room [1] [2] [3] [4]. In addition, regular maintenance of air conditioning equipment must be considered, in order to get optimal work [5] [6] [7].

From the description of previous studies, in connection with the process of controlling the work of the air conditioner, it is still in the location where the air conditioner is installed. The problem is that if the air conditioner forgets to turn it off and continues to operate, it will have an impact on the consumption of electrical energy and can cause a waste of electricity. For this reason, it is necessary to make a system prototype that can control the work of remote air conditioning equipment, by utilizing the IoT concept, so that users can remote wherever the user is if they forget to turn off the air conditioner, in order to avoid wasting electricity.

The process of controlling the work of AC equipment remotely is carried out via an Android smartphone media that has been implanted with an Android application to control AC work. Air conditioning equipment work control includes: On / Off process, operating mode settings and temperature settings for $\mathrm{AC}$ equipment. The communication process between the Android smartphone and the controller is done wirelessly via a web server application.

In producing a work control system for IoT-based air conditioning equipment, the method used is the prototyping method, where the stages begin with a literature study which aims to obtain references in accordance with this research; Android, where Android is a Linux-based operating system designed for touch screen mobile devices such as smartphones and tablet computers. In this study, android is used to create an application program for controlling the work of IoT-based air conditioning equipment [8]; The Arduino uno can be programmed with the Arduino software. At the ATMega328 on the Arduino there is a bootloader that allows you to upload new code without using an external hardware programmer. Arduino IDE is software written in Java. In this research, Arduino IDE software is used as a medium in making programs for the needs of IoT-based air conditioning equipment work control systems [9]; NodeMCU is an open source IoT platform and development kit that uses the Lua programming language to assist in making IoT product prototypes or can use sketch with the Adruino IDE. This development kit is based on the ESP8266 module, which integrates GPIO, PWM (Pulse Width Modulation), IIC, 1Wire and ADC (Analog to Digital Converter) all on one board. In this study, NodeMCU ESP8266 is used as a controller and data processor in an IoT-based working control system for air conditioning equipment [10].

The next stage is the stage of designing and making the system, where at this stage the process of designing and manufacturing hardware is carried out in the form of a system block diagram and software in the form of a system work algorithm. To get data related to the work of the system being made, the system testing process is carried out.

Sudies related to this research are as follows:

1. Application of the Internet of Things (IoT) in Learning at UNISNU Jepara, conducted by Dias Prihatmoko, 2016, where the research was carried out to produce an LED Light Control System that can be used to control LED lights automatically using the web [11].

2. Internet of Things (IoT) System Based on Cloud Computing in the Campus Area Network, which was carried out by Oris Krianto Sulaiman et al., 2017. Results In campus networks or known as campus area networks are very good for handling networks within the campus because they already exist redundancy in each connected link, by using the Internet of Things system which is integrated with cloud computing, the use of the campus network in education can be better [12]. 
3. Master Plan for Managing Distribution of Disaster Assistance with the Concept of Internet of Things (IoT) in North Maluku Province, which was carried out by Mohamad Jamil et al, 2017. Results, can help the community and local government in monitoring the disaster distribution process, namely when a disaster occurs or after a disaster. disaster, the process of distributing aid will be easier to distribute to disaster victims and on target, resulting in good governance processes in disaster management, because the system is

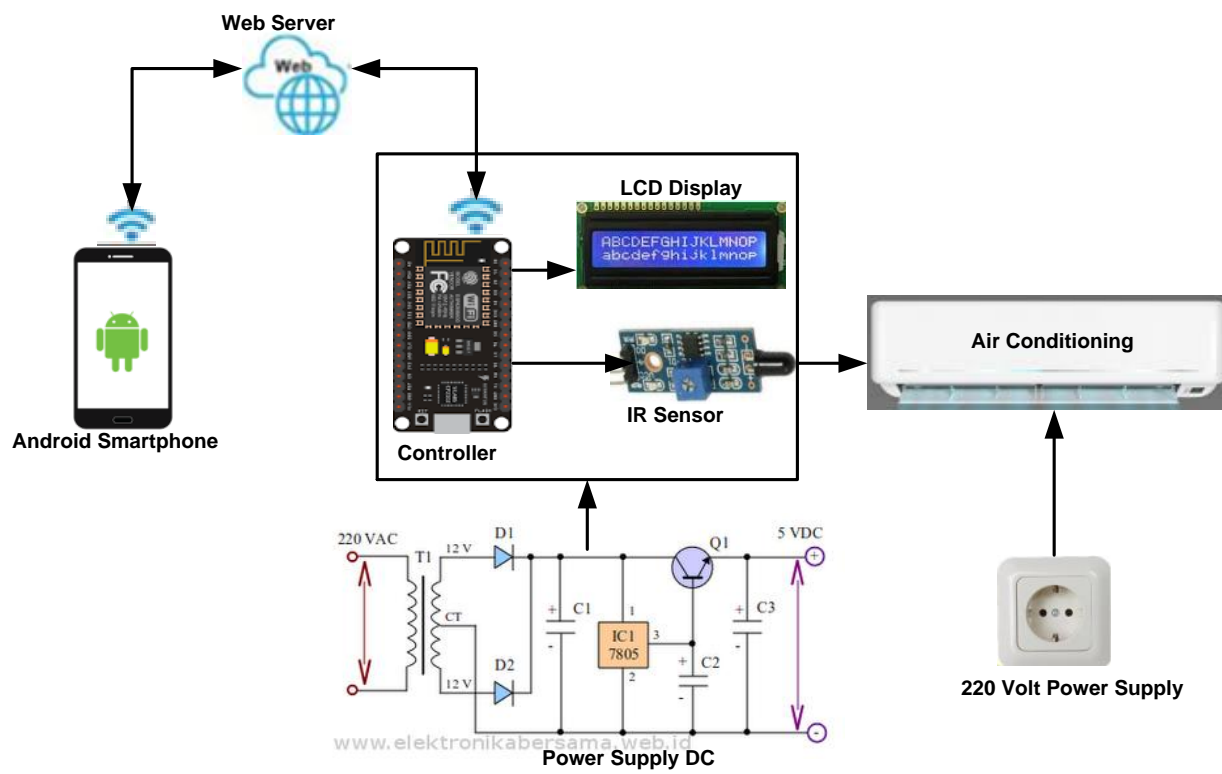

Fig 1: Block diagram system made using information technology media [13].

\section{SYSTEM DESIGN}

The system design is made in the form of a block diagram that describes the relationship between input / output and the controller, and represents the work of the system for the process of controlling the work of air conditioning equipment based on the Internet of Things (IoT). The hardware design in the form of a block diagram is shown in Figure 1.
The description of the Block diagram in Figure 1, is described as follows:

1. Android smartphone, serves as a medium for controlling the work of air conditioning equipment through an embedded Android application.

2. The nodeMCU ESP 8266 controller functions as a data processing center for controlling the work of air conditioning equipment.

3. The web server functions as an intermediary medium for communication between smartphone devices and controllers for the work control process of air conditioning equipment.

4. LCD screen, a display medium, to display information about the process of controlling air conditioning equipment.

5. IR (InfraRed) sensor, functions as a medium for sending data from the controller to the air conditioning equipment for controlling the work of the air conditioning equipment.

6. DC power supply, serves as a medium for supplying electricity to equipment: controllers, IR sensors and LCD screens.

\section{DESIGN AND DEVELOPMENT OF SOFTWARE}

For the work operation of the IoT-based air conditioning equipment control system, software is needed which includes: software for system work to be embedded in the controller for the work control process of air conditioning equipment, software in the form of an android application for the process of controlling the work of remote $\mathrm{AC}$ equipment and software for the web server that functions as an intermediary for controlling the smartphone to the controller or vice versa.

\subsection{System Algorithm (flow chart) For Controller Needs}

Algorithm (flow chart) for controller needs, aims to describe the order and function of the work control system of air conditioning equipment, to control the work of air conditioning equipment, in relation to on / off, setting work mode and temperature regulation.

The description of the algorithm is as follows: When the system is first activated, the controller will perform the system setup and synchronization process, and will connect to the web server. After the connection process with the web server is complete, the controller will then read the data received from the web server. The data that the controller receives from the web server is related to the on / off process, the operation mode setting process or the temperature setting process of the air conditioning equipment. For example, if the data received is data to activate the air conditioner, the controller will process the data, then the controller will send data to activate the air conditioner via the IR sensor and the controller will display information via the LCD display that the $\mathrm{AC}$ is active. after the process of activating the air conditioner and the information process via the LCD display is complete, the controller will read the data from the web server. This process will run continuously, until the system is disabled. The system flow diagram is shown in Figure 2. 


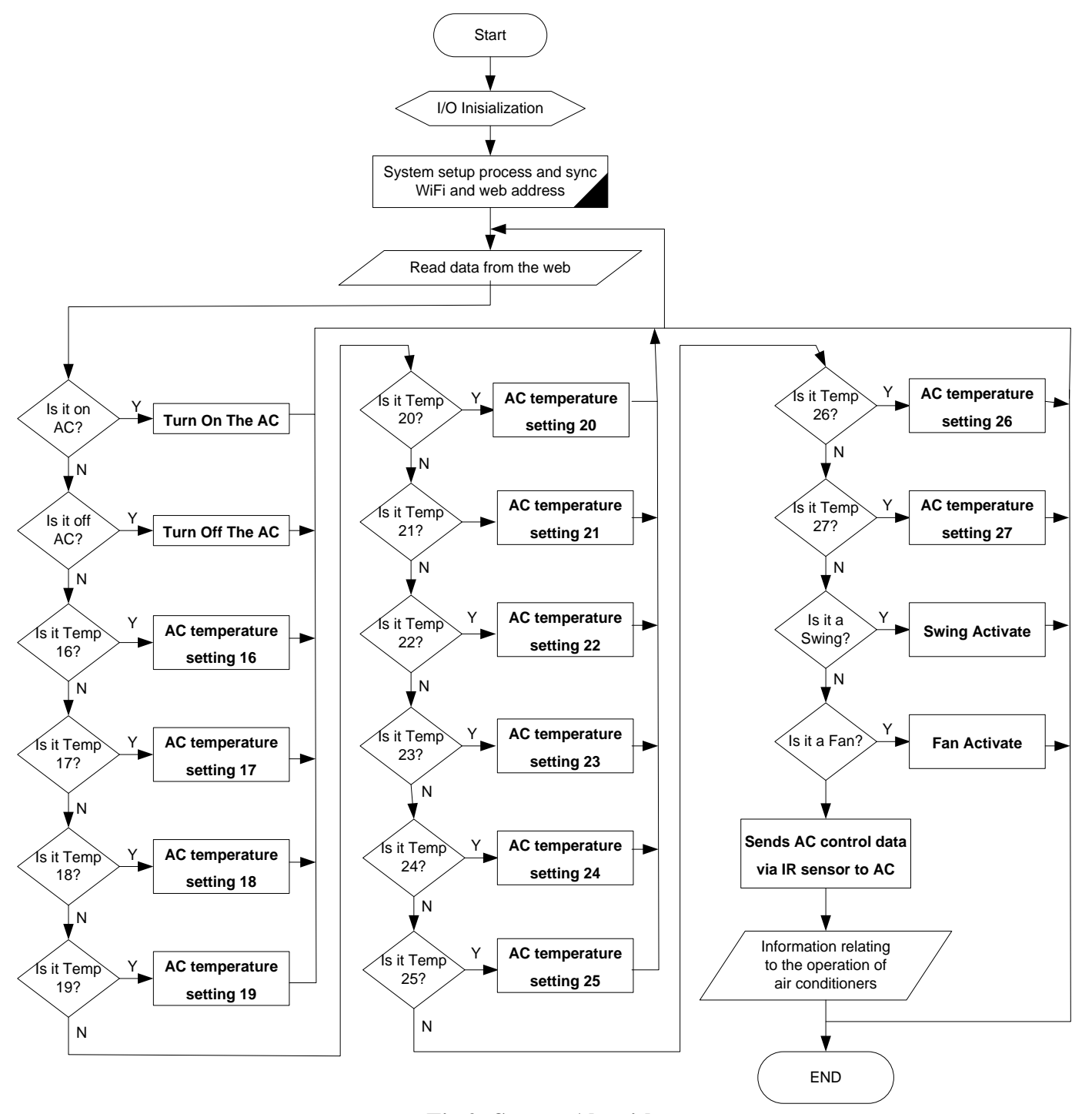

Fig 2: System Algorithm

To get initial data with respect to operating data from air conditioning equipment, data collection is carried out in connection with controlling air conditioning work. The data needed is data that will be sent to the air conditioning equipment as data for the on / off process of air conditioning, on / off swing, setting fan speed and setting air conditioning temperature settings. The air conditioning equipment used as a testing medium was an air conditioner under the LG brand with a capacity of $1 / 2 \mathrm{PK}$. Infrared sensor test data such as those shown in Table 1.

Table 1. Infrared sensor test data

\begin{tabular}{|c|c|c|}
\hline No & IR Sensor Data & Function \\
\hline 1 & 0x880095E & AC Activate \\
\hline 2 & 0x88C0051 & AC Deactivate \\
\hline 3 & 0x8810001 & Swing Activate \\
\hline 4 & 0x8810002 & Deactivate Swing \\
\hline 5 & 0x8808109 & Low Mode Fan \\
\hline
\end{tabular}

\begin{tabular}{|c|c|c|}
\hline 6 & 0x880812B & Mid Mode Fan \\
\hline 7 & 0x880814D & High Mode Fan \\
\hline 8 & $0 x 880815 \mathrm{E}$ & Temperature Setting $16^{\circ} \mathrm{C}$ \\
\hline 9 & $0 x 880825 \mathrm{~F}$ & Temperature Setting $17^{\circ} \mathrm{C}$ \\
\hline 10 & $0 x 8808350$ & Temperature Setting $18^{\circ} \mathrm{C}$ \\
\hline 11 & $0 x 8808451$ & Temperature Setting $19^{\circ} \mathrm{C}$ \\
\hline 12 & $0 x 8808552$ & Temperature Setting $20^{\circ} \mathrm{C}$ \\
\hline 13 & $0 x 8808653$ & Temperature Setting $21^{\circ} \mathrm{C}$ \\
\hline 14 & $0 x 8808754$ & Temperature Setting $22^{\circ} \mathrm{C}$ \\
\hline 15 & $0 x 8808855$ & Temperature Setting $23^{\circ} \mathrm{C}$ \\
\hline 16 & $0 x 8808956$ & Temperature Setting $24^{\circ} \mathrm{C}$ \\
\hline 17 & $0 x 8808957$ & Temperature Setting $25^{\circ} \mathrm{C}$ \\
\hline 18 & $0 x 8808958$ & Temperature Setting $26^{\circ} \mathrm{C}$ \\
\hline 19 & $0 x 8808959$ & Temperature Setting $27^{\circ} \mathrm{C}$ \\
\hline
\end{tabular}

Making software for controller work needs, using the Arduino IDE software, with reference to the algorithm that has been generated, as shown in Figure 3 


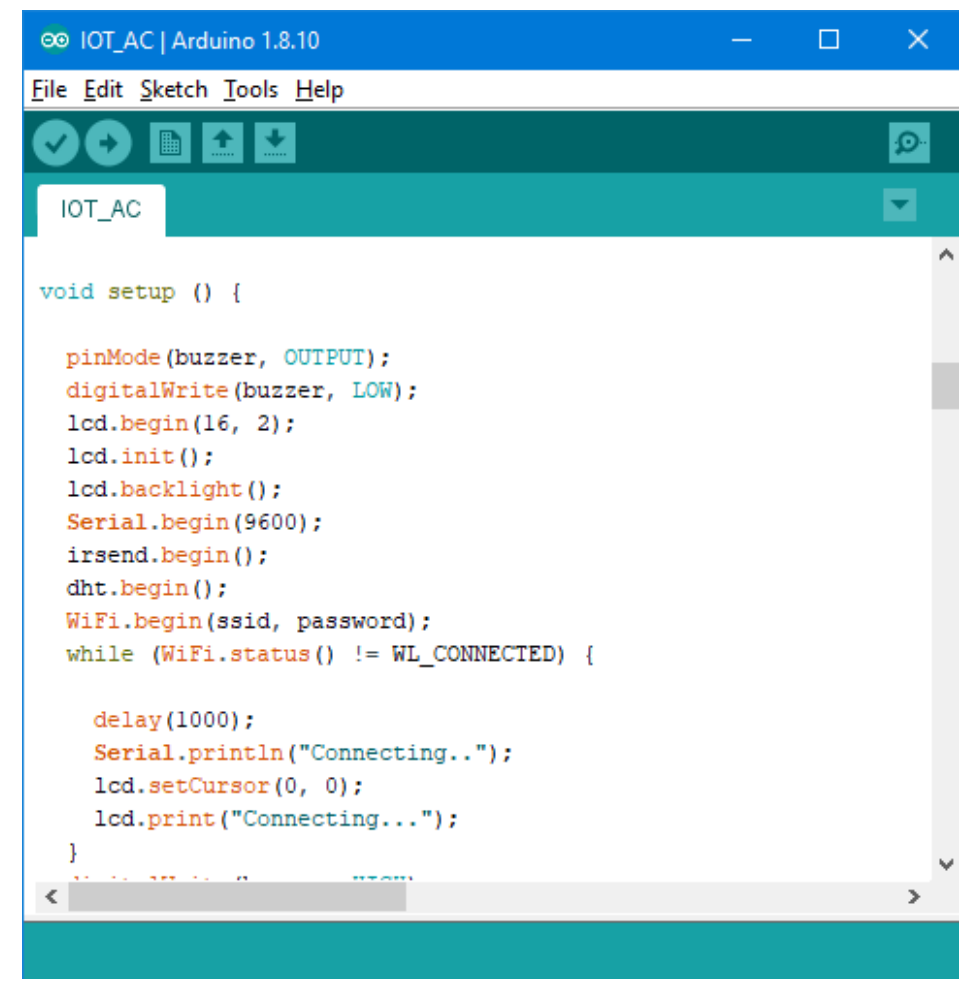

Fig 3: Programming via the Arduino IDE

\subsection{Web Server}

Creating a web server is done using PHP my Admin, where the web server functions as an intermediary for communication between the android smartphone installed with the smartIoT application and the nodeMCU controller, for the needs of controlling the work of air conditioning equipment. the web server display is shown in Figure 4.

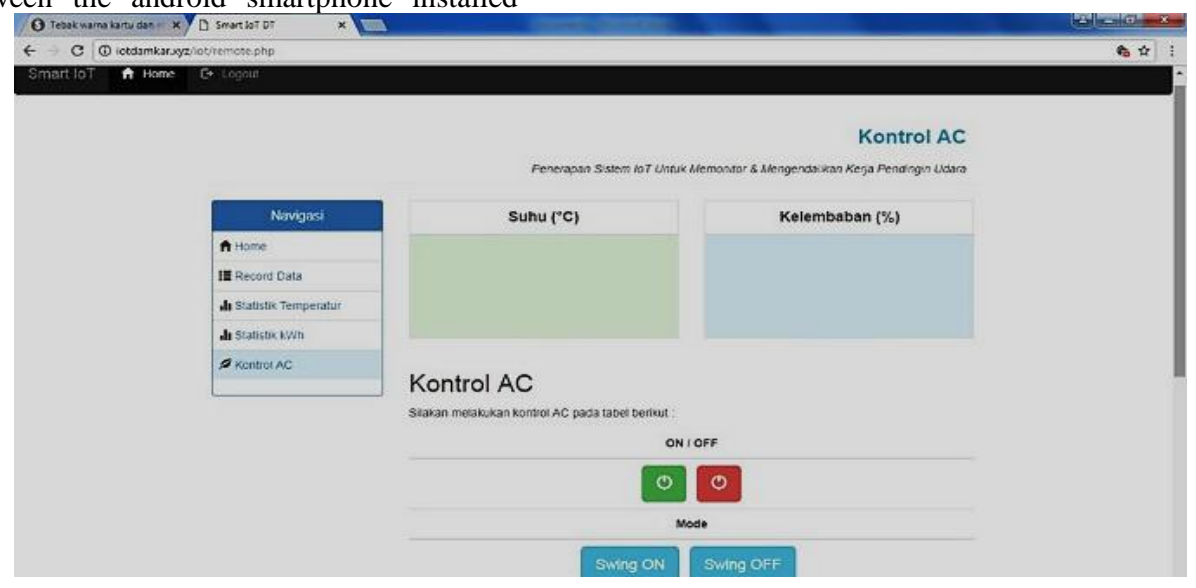

Fig 4: Web Server

\subsection{Android SmartIoT Application}

Making software for Android applications is done using the MIT app Inventor. Making software for android applications includes: making views for the login page, making views for the Home page, making displays for controlling pages of work operations of air conditioning equipment. The Android application appearance is shown in Figure 5. 

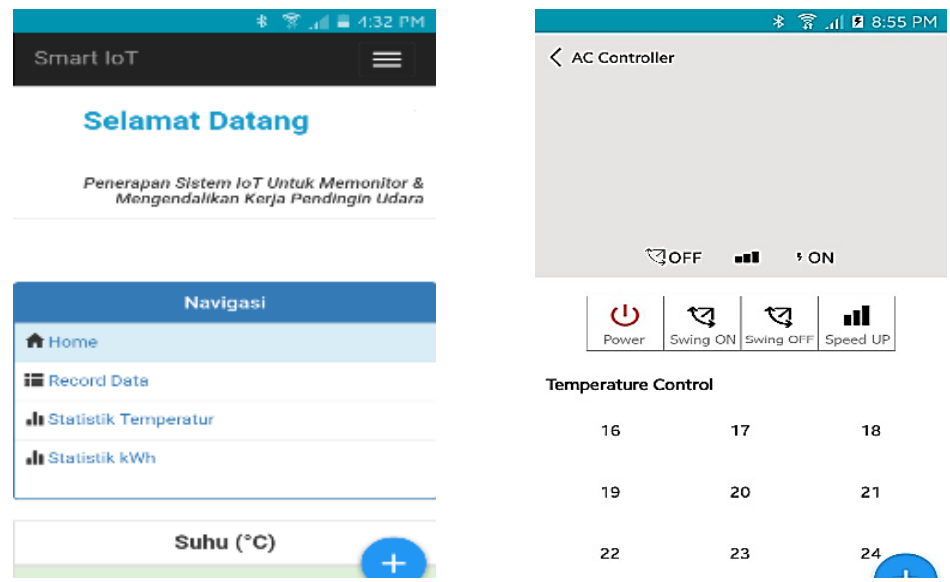

Fig 5: Android SmartIoT Application

\subsection{Hardware}

Hardware manufacturing is done by referring to the hardware design results in the form of block diagrams. Hardware manufacturing is done by combining modules such as: IR sensor module, LCD display module, and nodeMCU controller, so that they are integrated into one PCB board. The hardware for a work control system for IoT-based air conditioning equipment is shown in Figure 6.

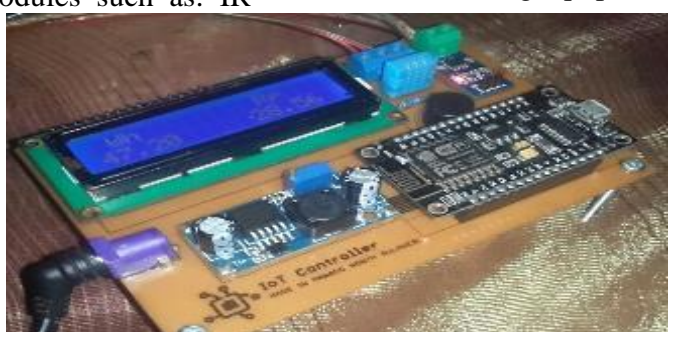

Fig 6: Hardware

\subsection{Sistem Simulation}

System simulation aims to simulate the work of the system created, whether it is in accordance with the design results or not. System simulation is carried out through the Proteus program. In this simulation program through proteus, simulations are carried out on the work of the system, in terms

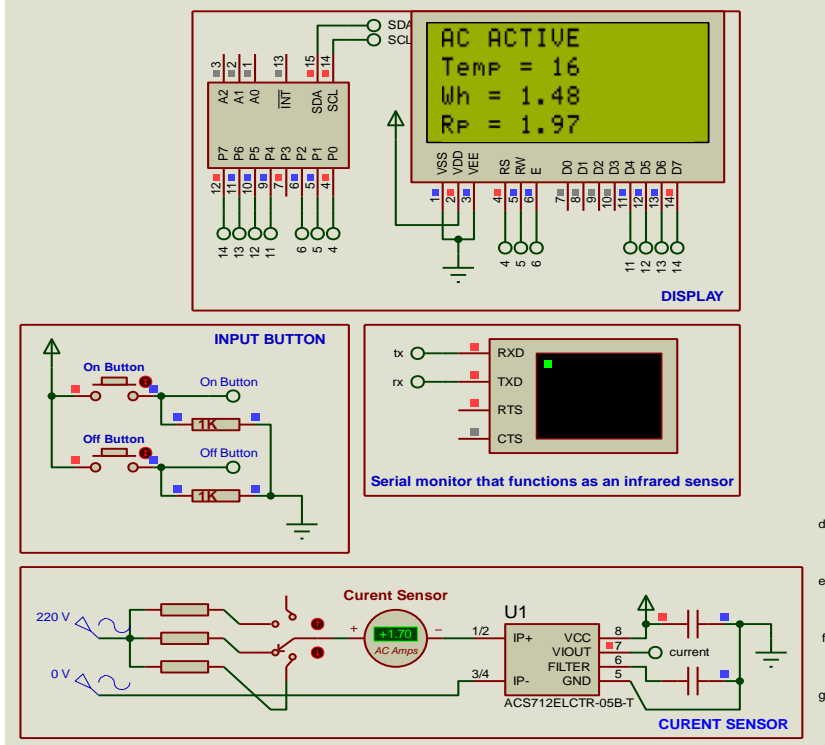

of the process of controlling the work of air conditioning equipment, which includes: on / off air conditioning, setting the operating mode and setting the working temperature of the air conditioning equipment. The system simulation is shown in Figure 7.

Fig 7: Sistem simulation on Proteus

\section{RESULTS AND DISCSSION}

\subsection{Simulations Testing}


To run a work control system simulation of IoT-based air conditioning equipment, embedded software is needed into the Arduino Uno controller. After the program is embedded into Arduino Uno, the next step is to run the system on the proteus simulation, by pressing the On Button, as shown in Figure 7.

After the start button is pressed, the system will process the communication setup between the controllers with a web server for the process of receiving and sending data, where the program parts are as follows:

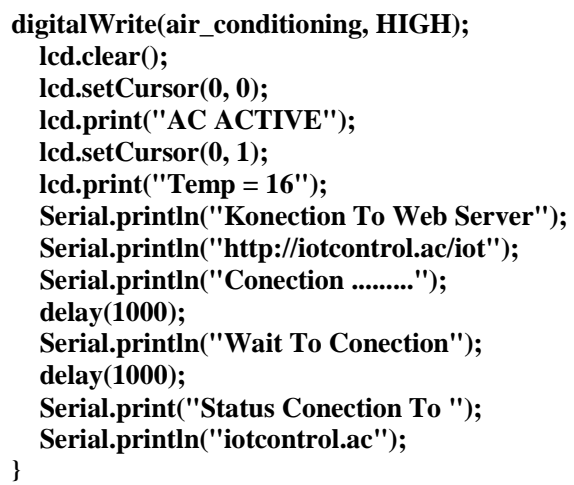

The work simulation of the system when running the above program is shown in Figure 8.

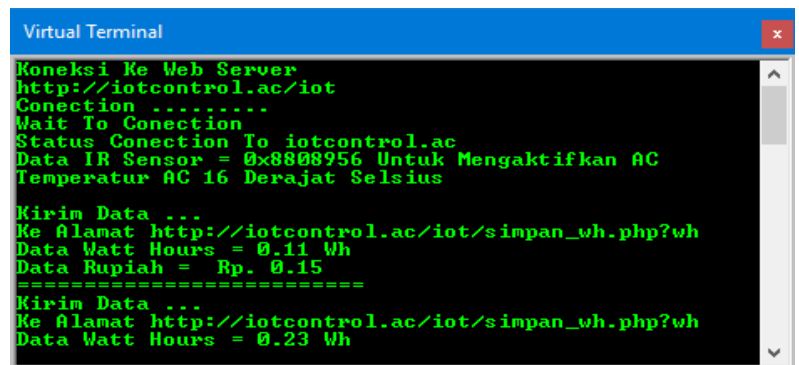

Fig 8: The work simulation of the system when running

From the simulation results as shown in Figure 8, it can be seen that when the start button is pressed, then the system will perform the process of opening a connection with the web server at the address http://iotcontrol.ac/iot.

The next stage is to read the incoming data that is sent via a web server, where the data is related to setting the working temperature of the air conditioning equipment. If the data received by the controller via a web server (which is simulated with a keypad) is data for temperature setting $17^{\circ} \mathrm{C}$, then the controller will be transmits $0 \times 880825 \mathrm{~F}$ data to air conditioning equipment via infrared sensors, for the working operation of air conditioning equipment at a temperature of $17^{\circ} \mathrm{C}$. As for the program being run to read data from the web server are as follows:

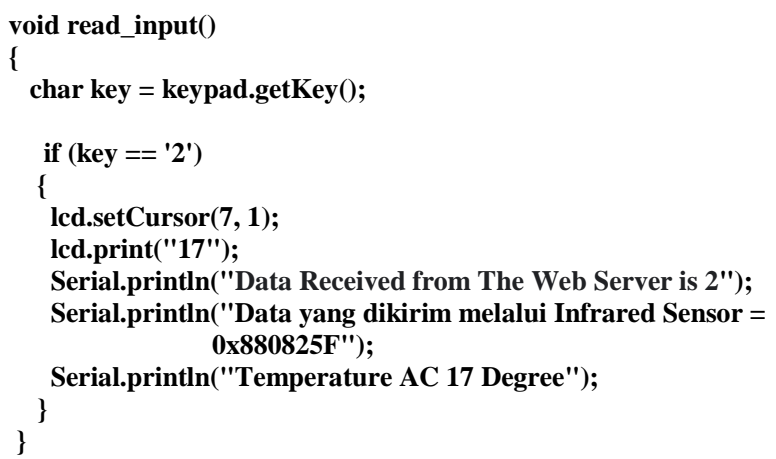

The simulation of the program above for temperature setting is $17^{\circ} \mathrm{C}$ as shown in Figure 9.

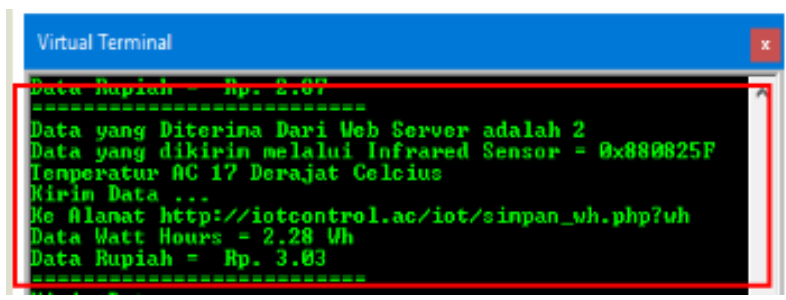

Fig 9: Temperature setting $17^{\circ} \mathrm{C}$

For the temperature setting testing process $18^{\circ} \mathrm{C}$ to $27^{\circ} \mathrm{C}$, the procedure is the same as for setting temperature $17^{\circ} \mathrm{C}$, only different in the comparison data received from the web server, and the data sent to the air conditioning equipment via infrared sensors.

\subsection{System Testing}

To carry out the process of controlling and monitoring the work of air conditioning equipment, it can be done via an Android smart phone through a smart IoT application program that is embedded in an Android smartphone, or via a web server.

The steps that can be taken for the process of controlling the work of air conditioning equipment, via an Android smartphone are as follows:

A. On / Off Control of Air Conditioning Equipment via Android Smart Phone

To carry out the process of activating the work of air conditioning equipment through the smart IoT application, what is done is to press the Power button. The activation of air conditioning equipment is indicated by a change in the indicator writing OFF to ON, as in Figure 10. The process of activating the work of air conditioning equipment when the power button is pressed is as follows:

- When the power button is pressed, the smart IoT application will connect to the web server. After the connection process is complete, the smart IoT application sends the "AC ON" data to the web server, then the data is sent from the web server to the controller.

- When the system is activated and the controller is connected to the web server, the controller will read data from the web server. If the data received from the web server is "AC ON", then the controller processes the data to activate the air conditioning equipment by sending data "0x880095E" to the air conditioning equipment via Infrared sensor transmission.

- Furthermore, the controller sends data to the android smart phone that the air conditioner is active, through changing the writing indicator from $\mathrm{OFF}$ to $\mathrm{ON}$, with the initial temperature setting at $16^{\circ} \mathrm{C}$. 


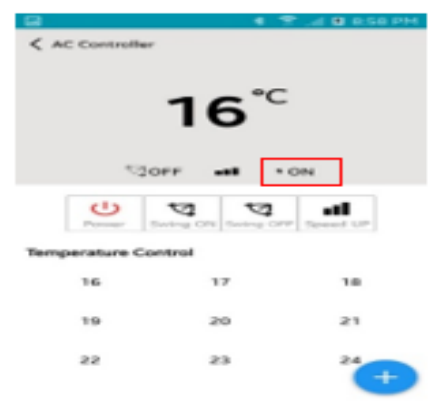

a). Activating the air conditioner

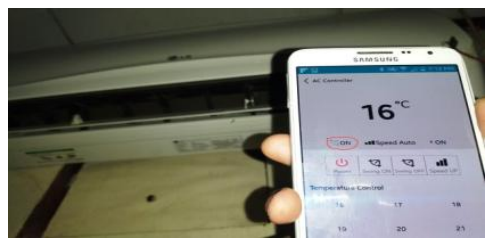

b) Testing the system activates the air conditioner

Fig 10: The process of activating the work of air conditioning equipment

To deactivate the work of air conditioning equipment, what is done is to re-press the power button on the smart IoT application. When the power button is pressed, the smart IoT application will send the "AC OFF" data to the web server and the web server will forward the data to the controller, then the controller will process the data to deactivate the air conditioning equipment by sending data "0x88C0051" via the sensor. infrared to air conditioning equipment.

B. Control of On / Off Swing of Air Conditioning Equipment via Android Smart Phone

Control of the work of the swing section of air conditioning equipment can be done by pressing the Swing On button to activate swing and Swing Off to deactivate Swing. When the controller receives data from the web server sent via the smart IoT application on the android smart phone in the form of "Swing On" data, the controller will activate the work of the swing section on the air conditioning equipment by sending data "0x8810001" to the air conditioning equipment via an infrared sensor. . The test results are as shown in Figure 11a. To deactivate swing work, what is done is to press the Swing Off button on the smart IoT application. The command is transmitted via the web server to the controller to deactivate the swing action of the air conditioning equipment. The controller will send data "0x8810002" to the air conditioning equipment via infrared sensors. The test results for the swing work deactivation process on air conditioning equipment are shown in Figure 11b.

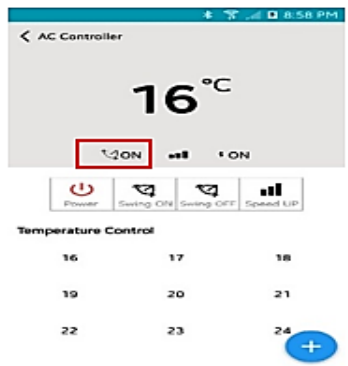

a

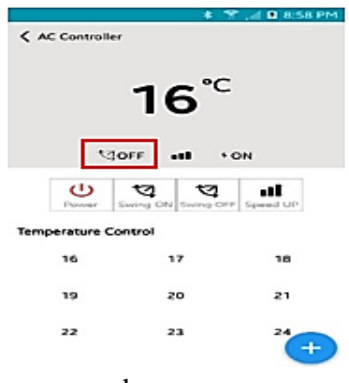

b
Fig 11: Enable and disable swing work

C. Control of Air Conditioning Equipment fan working

\section{mode via Android Smart Phone}

To control the fan working mode on air conditioning equipment, what is done is to press the Speed Up button on the smart IoT application. Setting the fan working mode consists of 3 parts of the settings which include: low mode fan, mid mode fan and high mode fan. When the controller receives low mode data from the web server, the controller sends data "0x8808109" via an infrared sensor to the air conditioner to activate the fan in low operating mode, where the test results are shown in Figure 12a. When the controller receives mid mode data from the web server, the controller sends data "0x880812B" via an infrared sensor to the air conditioner to activate the fan in mid operating mode, where the test results are shown in Figure 12b. When the controller receives High mode data from the web server, the controller sends data "0x880814D" through the infrared sensor to the air conditioner to activate the fan in High operating mode, where the test results are shown in Figure 12c.

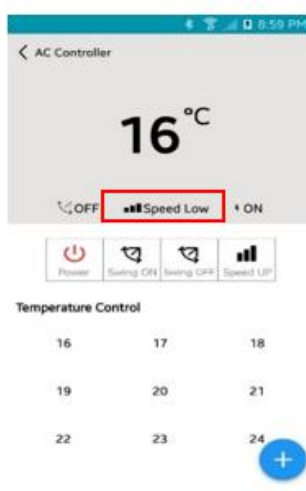

a. Low Mode

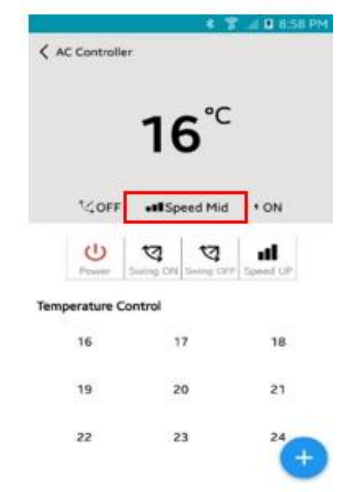

b. Mid Mode

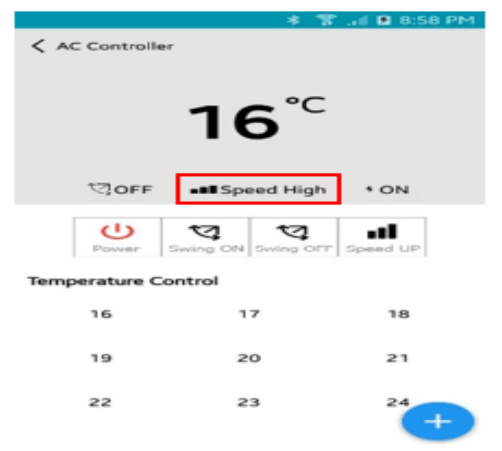

c. High Mode

Fig 12: Fan working setting mode

D. Controlling Air Conditioning Equipment Temperature Through an Android Smart Phone

The process of regulating the temperature of air conditioning equipment through the smart IoT application can be done by pressing one of the buttons on the Temperature Control section, where the temperature that can be selected ranges from $16^{\circ} \mathrm{C}$ to $27^{\circ} \mathrm{C}$. For example, for setting the temperature to $18^{\circ} \mathrm{C}$, what is done is to press the 18 button on the Temperature Control section. When the 18 button is pressed, the application sends the character data "Temperature 18" to the web server, then the web server continues the data to the controller. When the controller receives the character data "Temperature 18", the controller will process the data to adjust the operating temperature of the air conditioning equipment at $18^{\circ} \mathrm{C}$. The process of setting the $18^{\circ} \mathrm{C}$ temperature to air conditioning equipment by sending data 


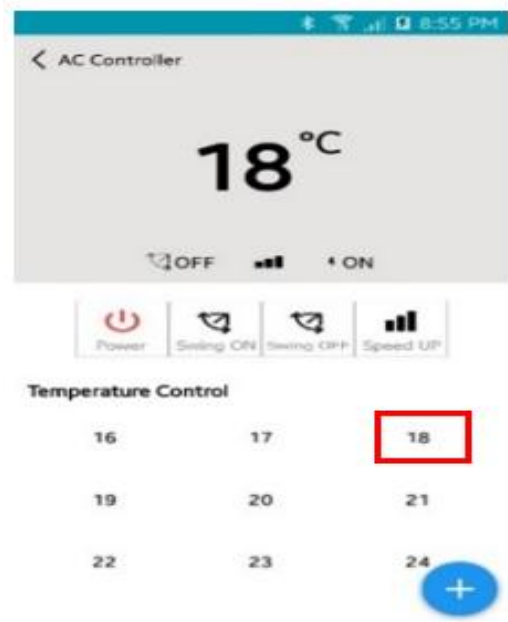

Fig 12: $18^{\circ} \mathrm{C}$ temperature setting

For the process of setting the working temperature of the air conditioning equipment as a whole is shown in Table 2.

Table 2. Testing data for the temperature setting process of air conditioning equipment

\begin{tabular}{|c|c|c|c|}
\hline $\begin{array}{c}\text { Air } \\
\text { Conditioning } \\
\text { Equipment } \\
\text { Working } \\
\text { Temperature } \\
\text { Regulation } \\
\left({ }^{\circ} \mathrm{C}\right)\end{array}$ & $\begin{array}{c}\text { Character } \\
\text { Data Sent } \\
\text { to } \\
\text { Controller } \\
\text { Via Smart } \\
\text { IoT }\end{array}$ & $\begin{array}{c}\text { Data Sent } \\
\text { Via } \\
\text { Infrared } \\
\text { Sensor }\end{array}$ & The results \\
\hline 16 & Temp 16 & $0 x 880815 \mathrm{E}$ & $\begin{array}{c}\text { Setting Temp } \\
16^{\circ} \mathrm{C}\end{array}$ \\
\hline 17 & Temp 17 & $0 \times 880825 \mathrm{~F}$ & $\begin{array}{c}\text { Setting Temp } \\
17^{\circ} \mathrm{C} \\
\end{array}$ \\
\hline 18 & Temp 18 & $0 x 8808350$ & $\begin{array}{c}\text { Setting Temp } \\
18^{\circ} \mathrm{C}\end{array}$ \\
\hline 19 & Temp 19 & $0 x 8808451$ & $\begin{array}{c}\text { Setting Temp } \\
19^{\circ} \mathrm{C}\end{array}$ \\
\hline 20 & Temp 20 & $0 x 8808552$ & $\begin{array}{c}\text { Setting Temp } \\
20^{\circ} \mathrm{C}\end{array}$ \\
\hline 21 & Temp 21 & $0 \times 8808653$ & $\begin{array}{c}\text { Setting Temp } \\
21^{\circ} \mathrm{C}\end{array}$ \\
\hline 22 & Temp 22 & 0x8808754 & $\begin{array}{c}\text { Setting Temp } \\
22^{\circ} \mathrm{C}\end{array}$ \\
\hline 23 & Temp 23 & 0x8808855 & $\begin{array}{c}\text { Setting Temp } \\
23^{\circ} \mathrm{C}\end{array}$ \\
\hline 24 & Temp 24 & $0 x 8808956$ & $\begin{array}{c}\text { Setting Temp } \\
24^{\circ} \mathrm{C}\end{array}$ \\
\hline 25 & Temp 25 & 0x8808957 & $\begin{array}{c}\text { Setting Temp } \\
25^{\circ} \mathrm{C}\end{array}$ \\
\hline 26 & Temp 26 & 0x8808958 & $\begin{array}{c}\text { Setting Temp } \\
26^{\circ} \mathrm{C} \\
\end{array}$ \\
\hline 27 & Temp 27 & 0x8808959 & $\begin{array}{c}\text { Setting Temp } \\
27^{\circ} \mathrm{C}\end{array}$ \\
\hline
\end{tabular}

From the results of the tests carried out, the prototype of the work control system for IoT-based air conditioning equipment can carry out the control process (Remote) of the operation of the air conditioner. Air conditioning equipment work control that can be done includes: On / Off, operating mode settings and temperature settings. The prototype system that is created can also avoid wasting electricity, through the process of deactivating remote air conditioning, if the air conditioning equipment is forgotten to turn off.

\section{CONCLUSIONS}

From the results of the research conducted, it can be concluded that the system created can carry out the work control process of air conditioning equipment through internet communication, with the concept of the Internet of Things. The control process can be done via an android smart phone that has an IoT smart application installed, via a web server, where data from the web server will be sent to the controller which functions as a control center for the work of air conditioning equipment, where the control includes: controlling on / off of the equipment Air conditioning, setting fan mode, setting on / off swing and setting working temperature settings of air conditioning equipment. For example, for the process of controlling the working temperature of the air conditioning equipment for $18^{\circ} \mathrm{C}$, the process carried out is pressing the 18 Button in the Temperature Control section of the smart IoT application, where the character data sent when the 18 Button is pressed is "Temperature 18". The character data is sent to the controller via a web server, then the controller processes the data to adjust the working temperature of the air conditioning equipment at $18^{\circ} \mathrm{C}$. The process of setting the temperature at $18^{\circ} \mathrm{C}$ is done by sending $0 \times 8808350$ data to the air conditioning equipment via an infrared sensor.

\section{ACKNOWLEDGMENTS}

Many thanks to the organizers of the International Journal of Computer Application (IJCA) which has provided an opportunity for authors to publish this paper and to the Ministry of Research and Technology who has funded this research so as to produce a scientific work as well as to the Manado State Polytechnic Institute as well Colleagues who have helped so much that the author can complete this writing.

\section{REFERENCES}

[1] Iksal, Saefudin, Ilham Asward, "Rancang Bangun Sistem Pengendali Suhu Ruang Menggunakan Fuzzy Logic", Jurnal Penelitian Dan Pengabdian Pada Masyarakat (ETOS), Vol. 4, No. 2, Juni, 2016.

[2] Kartina Diah KW, Zulva Noviardi, "Penerapan Inferensi Fuzzy Untuk Kendali Suhu Ruang Pada Pendingin Ruangan (AC)", Seminar Nasional Informatika 2010 UPN Veteran Yogyakarta, Mei 2010.

[3] Faizal Wahab, Arif Sumardino, Adnan Rafi Tatawi, Agus F.A. Mulayari, "Desain Dan Purwarupa Fuzzy Logic Control Untuk Pengendalian Suhu Ruangan”, Jurnal Teknologi Rekayasa (JTERA), Vol. 2, No. 1, Juni 2017.

[4] Ilham, Amil Ahmad, and Ali Ramschie. "Sistem Monitoring Dan Kendali Kerja Air Conditioning Berbasis Mikrokontroler ATmega 8535", Jurnal Ristek Vol.2, No.1, Juni 2013.

[5] Ali A.S. Ramschie, Johan Makal, Veny Ponggawa, "Algorithms Air Conditioning Air Filter Detection System For Electric Energy Savings", International Journal of Computer Application (IJCA), Vol. 156 No. 8, 2016.

[6] Buntarto, "Service dan Reparasi AC", Graha Ilmu, Yogyakarta, 2009

[7] Handoko J, "Merawat dan Memperbaiki AC", Kawan Pustaka, Jakarta, 2009. 
International Journal of Computer Applications (0975 - 8887)

Volume 175 - No. 34, December 2020

[8] Istiyanto, J. 2014. Pengantar Elektronika \& Instrumentasi: Pendekatan Arduino \& Android. Yogyakarta: ANDI

[9] Alan G. Smith, "Introduction To Arduino", Alan G. Smith, 2011.

[10] User Manual V1.2 ESP8266 NodeMCU WiFi Devkit, Handson Technology

[11] Dias Prihatmoko, 2016, "Penerapan Internet Of Things (IoT) Dalam Pembelajaran di UNISNU Jepara” Jurnal

\section{SIMETRIS, Vol 7 No 2 November 2016}

[12] Oris Krianto Sulaiman, Adi Widarma, 2017, "Sistem Internet Of Things (IoT) Berbasis Cloud Computing Dalam Kampus Area Network", Seminar Nasional Fakultas Teknik UISU, Volume xxiii.

[13] Mohamad Jamil, Muh Ridwan Lessy, Muhammad Said, 2017, "Master Plan Penatakelolaan Distribusi Bantuan Bencana Dengan Konsep Internet Of Things (IOT) Di Propinsi Maluku Utara", Jurnal Sistem Informasi (JSI), Vol 9. 